\title{
Effect of Soil Properties on Tree Distribution across an Agricultural Landscape on a Tropical Mountain, Tanzania
}

\author{
Mathayo Mpanda Mathew ${ }^{1 *}$, Amos E. Majule², Fergus Sinclair ${ }^{3}$, Rob Marchant ${ }^{4}$ \\ ${ }^{1}$ World Agroforestry Centre (ICRAF), Dar es Salaam, Tanzania \\ ${ }^{2}$ Institute of Resource Assessment, University of Dar es Salaam, Tanzania \\ ${ }^{3}$ World Agroforestry Centre (ICRAF), Nairobi, Kenya \\ ${ }^{4}$ York Institute for Tropical Ecosystems, Environment Department, University of York, York, UK \\ Email: "m.mpanda@cgiar.org, amajule@yahoo.com, f.sinclair@cgiar.org, robert.marchant@york.ac.uk
}

Received 17 February 2016; accepted 24 April 2016; published 27 April 2016

Copyright (C) 2016 by authors and Scientific Research Publishing Inc.

This work is licensed under the Creative Commons Attribution International License (CC BY). http://creativecommons.org/licenses/by/4.0/

(c) (i) Open Access

\section{Abstract}

Distribution of tree species can result in many factors including environmental variables, biotic interaction and management. Better understanding of these interacting factors is crucial in planning management interventions especially in managed landscapes: this study on the effect of soil properties on tree species distribution in Kilimanjaro, Tanzania will aid in this. Standard tree inventory procedures and soil sampling techniques were used to survey 48 plots from altitudinal level of 680 to $1690 \mathrm{~m}$ a.s.l. along $25 \mathrm{~km}$ long transect. All trees $\geq 5 \mathrm{~cm}$ at DBH were recorded, while soils were sampled from top and subsoils $(0-20$ and $21-50 \mathrm{~cm}$ depths). Tree species distribution index was assessed through abundance and frequency, while species interaction with environmental variables was assessed using Detrended Correspondence Analysis. Distribution index indicated that $77 \%$ of tree species were categorized as rare, while $10 \%$ and $13 \%$ were categorized as occasional and abundant respectively. Soil organic carbon and moisture content have shown high correlation with tree species $(r>0.8, \mathrm{p}<0.01)$, while ExMg, soil pH, P, ExCa, ExK, ExNa and bulky density indicated less correlation $(r<0.2, p<0.001)$. The DCA-1 axis explained nearly $\mathbf{7 0 \%}$ of the relationships between soil properties and tree species distribution: suitability of tree species were influenced by soil properties across the land use systems which exhibited different soil types. Different tree species communities correspond differently with soil properties between the land use systems. Fewer tree species spread in the lowland, which is known to have saline soils. Therefore, despite intensive human management of the landscape, tree species indicated distribution patterns in line with the soil properties.

\footnotetext{
${ }^{*}$ Corresponding author.
}

How to cite this paper: Mathew, M.M., Majule, A.E., Sinclair, F. and Marchant, R. (2016) Effect of Soil Properties on Tree Distribution across an Agricultural Landscape on a Tropical Mountain, Tanzania. Open Journal of Ecology, 6, $264-276$. 


\section{Keywords}

\section{Species Communities, Trees on Farm, Agroforestry, Soil and Tree Interactions}

\section{Introduction}

Trees on farm provide multiple benefits of ecosystem services including food security that support human livelihood. They can further offer synergy between adaptation and mitigation in addressing climate change impacts [1]-[3]. Integration of trees on farming landscapes forms part of traditional farming systems in the tropics [4], with varying degrees of practices [5]. Recently, there has been a noticeable trend of increasing tree cover on farms which coincides with diminishing forest cover in the natural forests due to overexploitation and deforestation [6]-[9]. Increased tree cover on farm had got upper hand as smallholder farmers actively engaged in priority setting and selection process of desired tree species [10] [11].

The composition and structure of sustained tree-based landscapes can be shaped by environmental variables, institutional settings and socio-economic dynamics [12] [13]. The suitability of tree species communities depends mainly on environmental variables as demonstrated by ecological niche modelling [14]. However, the use of habitat suitability models has been limited due to deficiencies in regional datasets, poor predictive performances and inconsistencies in model projection using future climate conditions [15]. Alternatively, a combination of the niche modelling and ordination has been used to utilize the synergies of the two methods (e.g., [16]), while others have proposed multiple parallel ordination methods [17]. The choice of environmental variables greatly influences the outcome of the ordination and must include key environmental variables used including climate (temperature and precipitation), topography (elevation and slope) and soil properties [18] [19].

Most assessments on tree distributions using ordination methods have been conducted on natural forests and rangelands where natural disturbances and processes and environmental variables are key factors [20] [21]. This study attempts to improve the knowledge gap by inclusion of farmland in understanding influence of soil properties on tree species distribution. Specifically, the study attempted to, 1) characterize tree species diversity and their local use, and 2) determine distribution of tree species communities as influenced by soil properties.

\section{Materials and Methods}

\subsection{Study Site}

The study was conducted in Moshi district, which is among administrative districts within Kilimanjaro region in north-eastern Tanzania on the southern part of Mount Kilimanjaro (Figure 1). The study site is comprised of agricultural landscape that occupies the lower altitude of the Mount Kilimanjaro; below $1800 \mathrm{~m}$ a.s.l. and is categorized into three zones namely, upland (1800 - $1400 \mathrm{~m}$ a.s.l.), the midland (1400 - $900 \mathrm{~m}$ a.s.l.) and lowland (below $900 \mathrm{~m}$ a.s.l.), differentiated by topography, climatic conditions and associated land uses [22] [23]. The upland zone is characterized by precipitation range of 1250 - $2000 \mathrm{~mm}$ per annum and mean annual temperature of $24^{\circ} \mathrm{C}$; the midland zone receives precipitation ranges between 1000 and $1200 \mathrm{~mm}$ per annum and mean annual temperature of $26^{\circ} \mathrm{C}$; and, the lowland zone has annual mean temperature of $33^{\circ} \mathrm{C}$ and rainfall ranges between 400 and $900 \mathrm{~mm}$ per annum [22].

Mount Kilimanjaro is a stratovolcano made up of three main centres of Kibo, Mawenzi and Shira [24]. Soils are mover diverse especially in the midland (Haplic Phaeozom) and upland (Humic Nitisol), as a result of processes involving the volcanic ash [25], while in the lowland savannah plain it is classified as Eutric Fluvisol [26] [27]. Hydrological processes of the study area is very complex, comprised of heavy precipitation, snow and deep ground water infiltration from the higher altitudes, and about $96 \%$ of the water inflow originate from the forest belt [28] [29].

\subsection{Methods}

\subsubsection{Tree Stocks Assessment}

On-farm tree inventory was conducted using 1 ha square plot $(100 \mathrm{~m} \times 100 \mathrm{~m}$, Figure 2), laid along transect from around 1690 to $680 \mathrm{~m}$ a.s.l. A total of 50 plots were established, and distributed by 12 plots in the upland, 


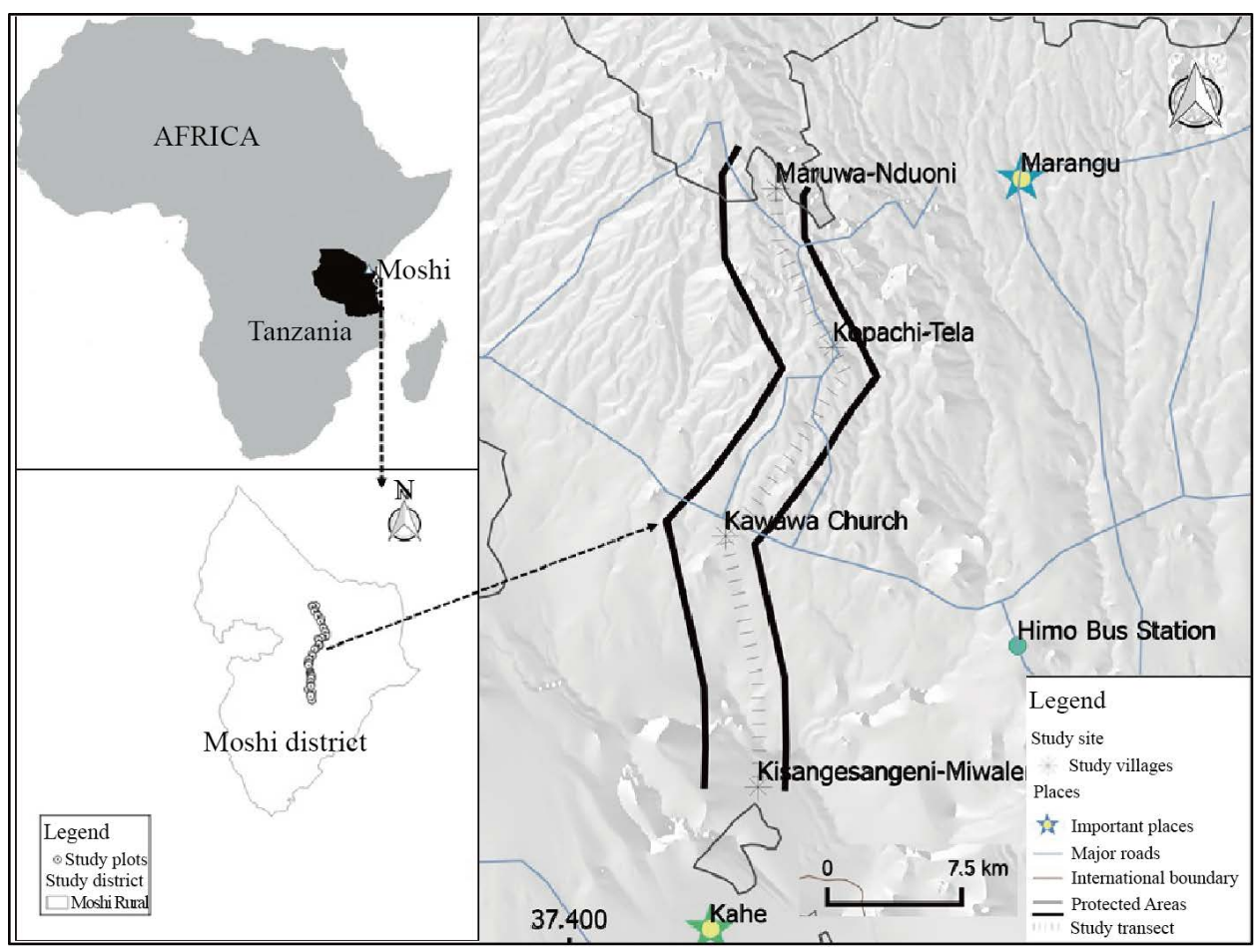

Figure 1. Location of the study site on the slopes of Mount Kilimanjaro, Tanzania.

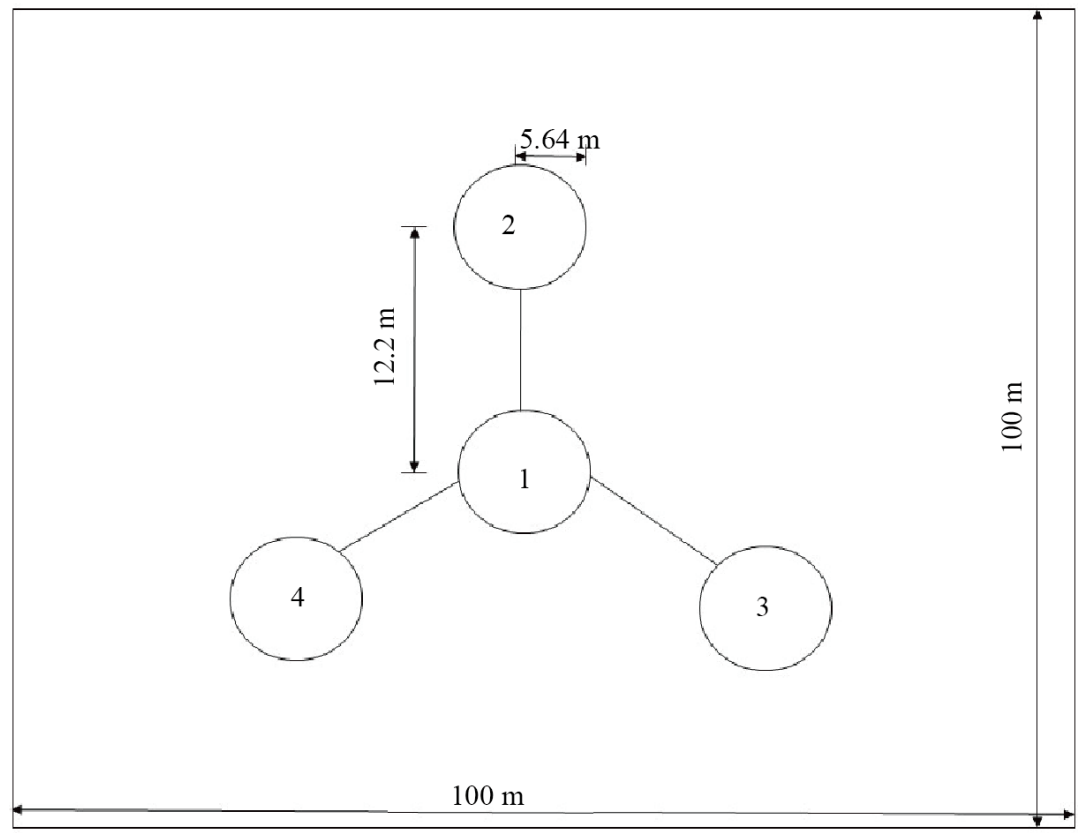

Figure 2. Plot layout for the tree inventory with nested four subplots $(1-4)$ used to collection of the soil samples.

14 plots in the midland and 24 plots in the lowland (however, two plots in the lowland were treeless hence removed from further analysis). In each plot all trees $\geq 5 \mathrm{~cm}$ diameter at breast height (DBH) were identified by use of botanist, their uses described by farmers within farm plots and recorded in the field note book (coffee shrubs and lianas were excluded).

The vegetation types of the recorded tree species were classified according to elevation using guideline produced by NAFORMA [30]. Tree species diversity was computed using distribution indices by expressions (1), 
(2) and (3);

$$
\begin{gathered}
\text { Abundance }=(\text { Individual } / \text { Total }) * 100 \\
\text { Frequency }=(\text { Plot } / \text { total plots }) * 100
\end{gathered}
$$

Distribution index $=$ Abundance + Frequency .

\subsubsection{Soil Properties Assessment}

Soil sampling plots were nested in the vegetation plots (Figure 2), using an inverted Y-shaped design adapted from AfSIS protocol [31]. Soil samples were collected at top $(0-20 \mathrm{~cm})$ and subsoils $(21-50 \mathrm{~cm})$ depth, at the four locations using the Y-shape for cumulative and composite samples. Cumulative soil sample was collected once at the centre (subplot 1) of each plot using an Edelman combination auger. A sampling plate was used as an auger guide to enable full recovery of the samples. Cumulative soil mass collected from top and subsoils were separately packed and labelled in zip-lock bags. Composite sample was collected in the four subplots (1 4), at top and subsoils, thoroughly mixed, and an estimated $700 \mathrm{~g}$ each from top and subsoils were packed separately in zip-locks and labelled.

All samples (cumulative and composite) were air dried in a large room and then weighed using calibrated top-pan balance to the nearest $0.1 \mathrm{~g}$. Oven-dried subsamples were ground using wooden rolling pin, then sieved through $2 \mathrm{~mm}$ mesh, and the remaining course fragments $>2 \mathrm{~mm}$ weighed. About $50-150 \mathrm{~g}$ of the cumulative samples were oven-dried at $105^{\circ} \mathrm{C}$ for approximately 48 hours until reached a constant weight. Gravimetric soil moisture content (MC) and bulky density (BD) were then computed using expressions (4) and (5);

$$
\begin{gathered}
\text { Gravimetric water content }(\%)=((\text { Air dried soil }- \text { Oven dried }) / \text { Oven dried }) * 100 \\
\text { Bulk density }\left(\mathrm{g} / \mathrm{cm}^{3}\right)=\mathrm{Md} / \mathrm{V}
\end{gathered}
$$

where; $\mathrm{Md}=$ mass of dry soil sample, $\mathrm{V}=$ soil volume

Air dried sub-samples from composite soil samples from top and subsoils each with approximately $20 \mathrm{~g}$ were loaded in to four wells and scanned using Fourier Transformation Mid Infrared Reflectance Spectroscopy at World Agroforestry Centre (ICRAF) Soil-Plant Spectral Diagnostics Laboratory in Nairobi. The soil samples were scanned 32 times and their four spectra averaged to account for variability within-sample and particle size and packaging in wells [32]. A sub-set of $30 \%$ of soil samples was randomly selected for wet chemistry analysis. These data were used for site-specific calibration and validation of the spectral predictions. Chemometric methods were used to predict soil properties from soil spectra and measured values of the reference soil samples [33]-[35]. The regression model developed from calibration was used to predict the soil properties for the rest of the samples and their coefficient of correlation $\left(\mathrm{R}^{2}\right)$ and root mean standard errors of calibration (RMSEC) are shown in Table 1.

\subsubsection{Statistical Analysis}

Detrended correspondence analysis (DCA) was conducted to determine species spread and individual positioning in the landscape, and their correspondences with soil properties [36]. Soil properties that were found to be significant $(\mathrm{p}<0.05)$ were considered for final DCA (Table 2, Figure 4). Additional analysis was done using

Table 1. Calibration results for soil properties on the slopes of Mount Kilimanjaro.

\begin{tabular}{ccc}
\hline Soil property $(\mathbf{n}=\mathbf{3 0})$ & \multicolumn{2}{c}{ Predictions } \\
\cline { 2 - 3 } & RMSEC & R-squared \\
\hline ExCa $(\mathrm{mg} / \mathrm{kg})$ & 0.41 & 0.89 \\
ExK $(\mathrm{mg} / \mathrm{kg})$ & 0.61 & 0.9 \\
ExMg $(\mathrm{mg} / \mathrm{kg})$ & 0.06 & 0.93 \\
P (mg/kg) & 1.13 & 0.21 \\
pH (1:2 soil:water) & 0.06 & 0.93 \\
ExNa (mg/kg) & 0.42 & 0.82 \\
\hline
\end{tabular}


Table 2. Soil parameters and their corresponding DCA values on distribution of tree species on the slopes of Mount Kilimanjaro, Tanzania.

\begin{tabular}{ccccc}
\hline Soil property & DCA-1 & DCA-2 & $\mathbf{r}^{2}$ & p (>r) \\
\hline Bulky density & -0.44689 & -0.89459 & 0.2499 & 0.007 \\
Moisture content (MC) & $\mathbf{0 . 8 5 1 6 5}$ & 0.52411 & 0.2299 & 0.016 \\
Soil organic carbon (SOC) & $\mathbf{0 . 9 4 1 9 6}$ & 0.33573 & 0.5690 & 0.001 \\
Soil pH & -0.46588 & -0.88485 & 0.6668 & 0.001 \\
ExCa & -0.75921 & -0.65085 & 0.3377 & 0.002 \\
P & -0.25139 & -0.96789 & 0.5637 & 0.001 \\
ExMg & -0.98141 & 0.19192 & 0.3065 & 0.003 \\
ExK & -0.36260 & -0.93194 & 0.4804 & 0.002 \\
ExNa & -0.35913 & -0.93329 & 0.3926 & 0.004 \\
\hline
\end{tabular}

Note: Eigenvalues for DCA-1 axis $=0.677$ and DCA-2 axis $=0.36$.

Sorenson's test to compare species spread among different land use zones. Species cumulative curves were drawn to show species increment with sampling sites, as an indicative measure of species diversity [37]. A normality test was conducted and indicated that all tree species distribution did not conform to normal tendency, hence non-parametric Kruskal Wallis (K-W) and Mann Whitney Wilcoxon (MWW) were used for statistical tests.

\section{Results}

\subsection{Species Diversity and Local Use}

A total of 69 species belonging to 28 families were recorded in the study site, comprised of multi-purpose tree species mainly catering for fruits, timber, fuelwood, and medicinal values (Table 3). At local scale, distribution index indicated that $77 \%$ of the species were rare, while $10 \%$ and $13 \%$ were occasional and abundant respectively. Species were found to overlap between land use zonesby more than $30 \%$ as indicated by Sorenson's in$\operatorname{dex}(s=0.33-0.38)$.

Detrended correspondence analysis (Figure 3(a)) indicated species spread in the lowland and clustering in the upland and the midland areas. Lowland plant communities have shown positive loadings along Axis-1, whilst upland plant communities showed negative loadings. Species were found to overlap between altitudinal zones by more than $30 \%$ as indicated by Sorenson's index $(s=0.33-0.38)$. Species cumulative curves (Figure 3(b)) indicated increment of tree species with increased sampling sites. Rate of species accumulation differed between the three land use zones and was steepest in the midland, and shallower in the lowland.

Species richness (Figure 4(a)) exhibited a humped-shaped curve with altitude, increasing from the lowland up to the midland, and thereafter declining towards the upland, though the patterns did not show statistical differences (K-W: $d f=40, p=0.294)$. Using land use zones the same trend was observed (Figure 4(b)), with species richness highest in the midland followed by the upland, and lowest in the lowland. The differences were significant for the upland $v$ s lowland (MWW test: $\mathrm{df}=1, \mathrm{p}<0.001$ ) and the midland $v s$ lowland $(\mathrm{p}<0.001)$ but not for the upland vs midland $(\mathrm{p}=0.641$ ). Species evenness (Figure $4(\mathrm{c})$ ) decreased with increasing altitude. In general, the lowland area was found to have higher species evenness (Figure 4(d)) indicating less variation in number of species groups, though the variation was not significant (K-W test: $\mathrm{df}=40, \mathrm{p}=0.615$ ). Further statistical tests indicated that there was no difference between species evenness between the upland vs midland (MWW test: $\mathrm{df}=1, \mathrm{p}=0.297)$, but observe differences between the upland $v$ s lowland $(\mathrm{p}=0.016)$, and the midland $v$ s lowland $(\mathrm{p}=0.002)$.

\subsection{Soil Properties and Tree Species Distribution}

Results from DCA indicated an overlap in tree species distribution in part of the upland and midland that were influenced by SOC and MC (Figure 5). Furthermore, ExMg influenced distribution of tree species mainly in the midland with some overlaps in the upland. Exchangeable bases (Ca, Na and K), available P, soil pH and BD indicated influence on distribution of lowland species. 
Table 3. On-farm tree species abundance and their uses on slopes of Mount Kilimanjaro, Tanzania.

\begin{tabular}{|c|c|c|c|c|c|c|c|}
\hline Abbrev. & Species name & Family & Freq & Abun & $\begin{array}{l}\text { Distr. } \\
\text { index }\end{array}$ & Veg. & Local uses \\
\hline PAM & Persea americana & Lauraceae & 40 & 17.0 & 57.0 & SM & Fruit, timber, fuelwood, shade \\
\hline GRO & Grevillea robusta & Proteaceae & 44 & 11.4 & 55.4 & SM \& L & Timber, fuelwood, withies, \\
\hline $\mathrm{BM}$ & Bridelia micrantha & Euphorbiaceae & 48 & 5.2 & 53.2 & SM \& L & $\begin{array}{l}\text { Fruits, timber, fuelwood, fodder, } \\
\text { gum/resins, tannin, medicine, shade }\end{array}$ \\
\hline ABS & Albizia schimperiana & Fabaceae - Mimosoideae & 42 & 8.6 & 50.6 & SM \& L & Timber, shade, fuelwood, medicinal, \\
\hline MGI & Mangifera indica & Anacardiaceae & 32 & 11.2 & 43.2 & SM & Fruits, fuelwood, timber \\
\hline OCA & Olea capensis & Oleaceae & 32 & 9.8 & 41.8 & SM \& L & Timber, fodder, fuelwood \\
\hline RCA & Rauvolfia caffra & Apocynaceae & 34 & 5.4 & 39.4 & SM \& L & $\begin{array}{l}\text { Timber, fuelwood, fodder, medicine, } \\
\text { alcohol }\end{array}$ \\
\hline $\mathrm{COA}$ & Cordia africana & Boraginaceae & 30 & 2.0 & 32.0 & SM \& L & Timber, fuelwood, fodder, fruit \\
\hline AI & Azadirachta indica & Meliaceae & 18 & 2.2 & 20.2 & SM \& L & Fruits, medicinal \\
\hline FHA & Faidherbia albida & Fabaceae - Mimosoideae & 16 & 4.0 & 20.0 & $\mathrm{~L}$ & $\begin{array}{l}\text { Soil fertility, soil erosion control, } \\
\text { fodder }\end{array}$ \\
\hline CTSp & Croton macrostachys & Euphorbiaceae & 18 & 1.9 & 19.9 & SM \& L & $\begin{array}{l}\text { Fuelwood, timber, fodder, shade, } \\
\text { medicine, ornamental }\end{array}$ \\
\hline SSI & Senna siamea & Fabaceae - Caesalpinioideae & 12 & 4.4 & 16.4 & $\mathrm{~L}$ & $\begin{array}{l}\text { Fuelwood, poles, timber, fodder, } \\
\text { medicine, shade }\end{array}$ \\
\hline EUT & Euphorbia tirucalli & Euphorbiaceae & 14 & 2.3 & 16.3 & $\mathrm{~L}$ & Fencing, medicinal \\
\hline MOB & Markhamia lutea & Bignoniaceae & 14 & 0.7 & 14.7 & $\mathrm{~L}$ & Medicinal, firewood \\
\hline FTH & Ficus sur & Moraceae & 14 & 0.6 & 14.6 & $\mathrm{SM}$ & Catchment, shade \\
\hline OUS & Olinia usambarensis & Oliniaceae & 12 & 1.1 & 13.1 & SM \& L & Medicinal, poles, \\
\hline PGU & Psidium guajava & Myrtaceae & 8 & 0.7 & 8.7 & L & Fruits, medicinal \\
\hline ADI & Adansonia digitata & Bombacaceae & 8 & 0.5 & 8.5 & $\mathrm{~L}$ & Fruit, fodder, rope, twine \\
\hline SGU & Syzygium cumini & Myrtaceae & 8 & 0.4 & 8.4 & $\mathrm{~L}$ & Shade, edible fruits, medicinal \\
\hline $\mathrm{CSH}$ & Combretum stuhlmannii & Combretaceae & 8 & 0.3 & 8.3 & $\mathrm{~L}$ & Fuelwood, timber \\
\hline TAS & Toddalia asiatica & Rutaceae & 6 & 0.8 & 6.8 & $\mathrm{~L}$ & Medicinal, fodder, hedge \\
\hline EAB & Erythrina abyssinica & Fabaceae - Papilionoideae & 6 & 0.2 & 6.2 & $\mathrm{SM}$ & Medicinal, ornamental \\
\hline $\mathrm{JCM}$ & Jacaranda mimosifolia & Bignoniaceae & 6 & 0.2 & 6.2 & SM \& L & Timber, ornamental \\
\hline ABG & Albizia lebbeck & Fabaceae - Mimosoideae & 6 & 0.2 & 6.2 & SM \& L & Fuelwood, poles \\
\hline $\mathrm{ABL}$ & Albizia gumifera & Fabaceae - Mimosoideae & 6 & 0.2 & 6.2 & SM \& L & Timber \\
\hline EUC & Eucalyptus camadulensis & Myrtaceae & 4 & 1.4 & 5.4 & SM \& L & Poles, fuelwood, medicinal, shade \\
\hline AME & Acacia xanthophloea & Fabaceae - Mimosoideae & 4 & 0.9 & 4.9 & L & Firewood, beekeeping \\
\hline MLU & Markhamia obtusifolia & Bignoniaceae & 4 & 0.6 & 4.6 & $\mathrm{~L}$ & $\begin{array}{c}\text { Timber, fuelwood, medicine, poles, } \\
\text { shade }\end{array}$ \\
\hline CUS & Cussonia spicata & Araliaceae & 4 & 0.4 & 4.4 & SM \& L & Medicinal \\
\hline FSY & Ficus sycomorus & Moraceae & 4 & 0.3 & 4.3 & $\mathrm{~L}$ & Shade, Fruits \\
\hline $\mathrm{ABF}$ & Albizia forbesii & Fabaceae - Mimosoideae & 4 & 0.2 & 4.2 & $\mathrm{~L}$ & Fuelwood, poles \\
\hline SCB & Sclerocarya birrea & Anacardiaceae & 4 & 0.2 & 4.2 & $\mathrm{~L}$ & Edible fruits, Timber \\
\hline ATH & Artocarpus heterophyllus & Moraceae & 4 & 0.1 & 4.1 & $\mathrm{~L}$ & Fruit \\
\hline ECS & Eucalyptus maidenii & Myrtaceae & 4 & 0.1 & 4.1 & SM \& L & Timber \\
\hline LSC & Lannea schweinfurthii & Anacardiaceae & 4 & 0.1 & 4.1 & $\mathrm{~L}$ & Medicinal, edible fruits \\
\hline OIN & Ozoroa insignis & Anacardiaceae & 4 & 0.1 & 4.1 & $\mathrm{~L}$ & Edible fruits, medicinal \\
\hline PPA & Pinus patula & Pinaceae & 2 & 0.5 & 2.5 & $\mathrm{SM}$ & Timber, resins \\
\hline AGRA & Acacia mearnsii & Fabaceae - Mimosoideae & 2 & 0.4 & 2.4 & $\mathrm{~L}$ & Firewood \\
\hline APO & Acacia grandicornuta & Fabaceae - Mimosoideae & 2 & 0.2 & 2.2 & $\mathrm{~L}$ & Firewood, poles \\
\hline TAF & Treculia africana & Moraceae & 2 & 0.2 & 2.2 & SM \& L & Edible seeds, timber \\
\hline EJA & Eriobotrya japonica & Rosaceae & 2 & 0.2 & 2.2 & SM \& L & Edible fruits \\
\hline TIN & Tamarindus indica & Fabaceae - Caesalpinioideae & 2 & 0.2 & 2.2 & $\mathrm{~L}$ & Fruits, medicinal, shade \\
\hline
\end{tabular}




\begin{tabular}{|c|c|c|c|c|c|c|c|}
\hline TEM & Trichilia emetica & Meliaceae & 2 & 0.2 & 2.2 & $\mathrm{~L}$ & Timber, firewood, shade \\
\hline $\mathrm{CAB}$ & Casaeria battiscombei & Flacourticeae & 2 & 0.1 & 2.1 & SM \& L & Timber \\
\hline DXR & Delonix regia & Fabaceae - Caesalpinioideae & 2 & 0.1 & 2.1 & L & Ornamental \\
\hline FSP & Ficus thonningii & Moraceae & 2 & 0.1 & 2.1 & SM \& L & Shade, ornamental \\
\hline MAC & Maytenus acuminata & Celastraceae & 2 & 0.1 & 2.1 & SM & Firewood, tool handles \\
\hline MAZ & Melia azedarach & Meliaceae & 2 & 0.1 & 2.1 & Lowland & Timber, shade \\
\hline ACS & Acacia tortilis & Fabaceae - Mimosoideae & 2 & 0.1 & 2.1 & Lowland & Shade, timber, firewood \\
\hline ACT & Acacia mellifera & Fabaceae - Mimosoideae & 2 & 0.1 & 2.1 & SM \& L & Firewood, beekeeping \\
\hline AXA & Acacia polyacantha & Fabaceae - Mimosoideae & 2 & 0.1 & 2.1 & $\mathrm{~L}$ & Shade, firewood \\
\hline ACF & Acrocarpus fraxinifolius & Fabaceae - Caesalpinioideae & 2 & 0.1 & 2.1 & SM \& L & Timber and amenity \\
\hline AGA & Agave sp. & Asparagaceae - Agavaceae & 2 & 0.1 & 2.1 & $\mathrm{~L}$ & Poles, fences, ropes \\
\hline ANO & Anacardium occidentale & Anacardiaceae & 2 & 0.1 & 2.1 & $\mathrm{~L}$ & Agricultural crop, exotic \\
\hline ANS & Annona senegalensis & Annonaceae & 2 & 0.1 & 2.1 & $\mathrm{~L}$ & Fruits, medicinal, ropes \\
\hline ASQ & Annona squamosa & Annonaceae & 2 & 0.1 & 2.1 & $\mathrm{~L}$ & Fruits \\
\hline CED & Carissa edulis & Apocynaceae & 2 & 0.1 & 2.1 & SM \& L & Fruits, medicinal \\
\hline CTL & Citrus limon & Rutaceae & 2 & 0.1 & 2.1 & $\mathrm{~L}$ & Fruit \\
\hline CTS & Citrus sinensis & Rutaceae & 2 & 0.1 & 2.1 & $\mathrm{~L}$ & Fruit \\
\hline CRM & Croton megalocarpus & Euphorbiaceae & 2 & 0.1 & 2.1 & SM \& L & Medicinal, firewood \\
\hline CUL & Cuppressus lusitanica & Cupressaceae & 2 & 0.1 & 2.1 & SM & Timber, ornamental \\
\hline EVE & Ensete ventricosum & Musaceae & 2 & 0.1 & 2.1 & SM & Edible fruits, ornamental \\
\hline JTC & Jatropha caurcas & Euphorbiaceae & 2 & 0.1 & 2.1 & $\mathrm{~L}$ & Graveyard, biodiesel \\
\hline MEX & Milicia excelsa & Moraceae & 2 & 0.1 & 2.1 & $\mathrm{~L}$ & Timber \\
\hline MAL & Morus alba & Moraceae & 2 & 0.1 & 2.1 & SM \& L & Edible fruits \\
\hline PAF & Prunus africana & Rosaceae & 2 & 0.1 & 2.1 & SM \& L & Medicinal, timber \\
\hline SCU & Syzygium guineense & Myrtaceae & 2 & 0.1 & 2.1 & L & Fruits, medicinal, firewood, timber \\
\hline TGR & Tectona grandis & Verbenaceae & 2 & 0.1 & 2.1 & $\mathrm{~L}$ & Timber, fuelwood \\
\hline TCA & Terminalia catapa & Combretaceae & 2 & 0.1 & 2.1 & $\mathrm{~L}$ & Fruits, timber, ornamental \\
\hline
\end{tabular}

Veg. = Vegetation type: $\mathrm{SM}=$ Sub-montane vegetation, $\mathrm{L}=$ Lowland vegetation as described by (NAFORMA 2010), Abun = Abundance, Freq $=$ Frequency, Distr. index $=$ Distribution index, Abundant $>20$, Occasional $=10-20$, Rare $=0-10$ (Abundance $=$ total appearance of species in the entire study plots, Frequency $=$ the number of plots to which the species is present, Distribution index = Abundance + Frequency).
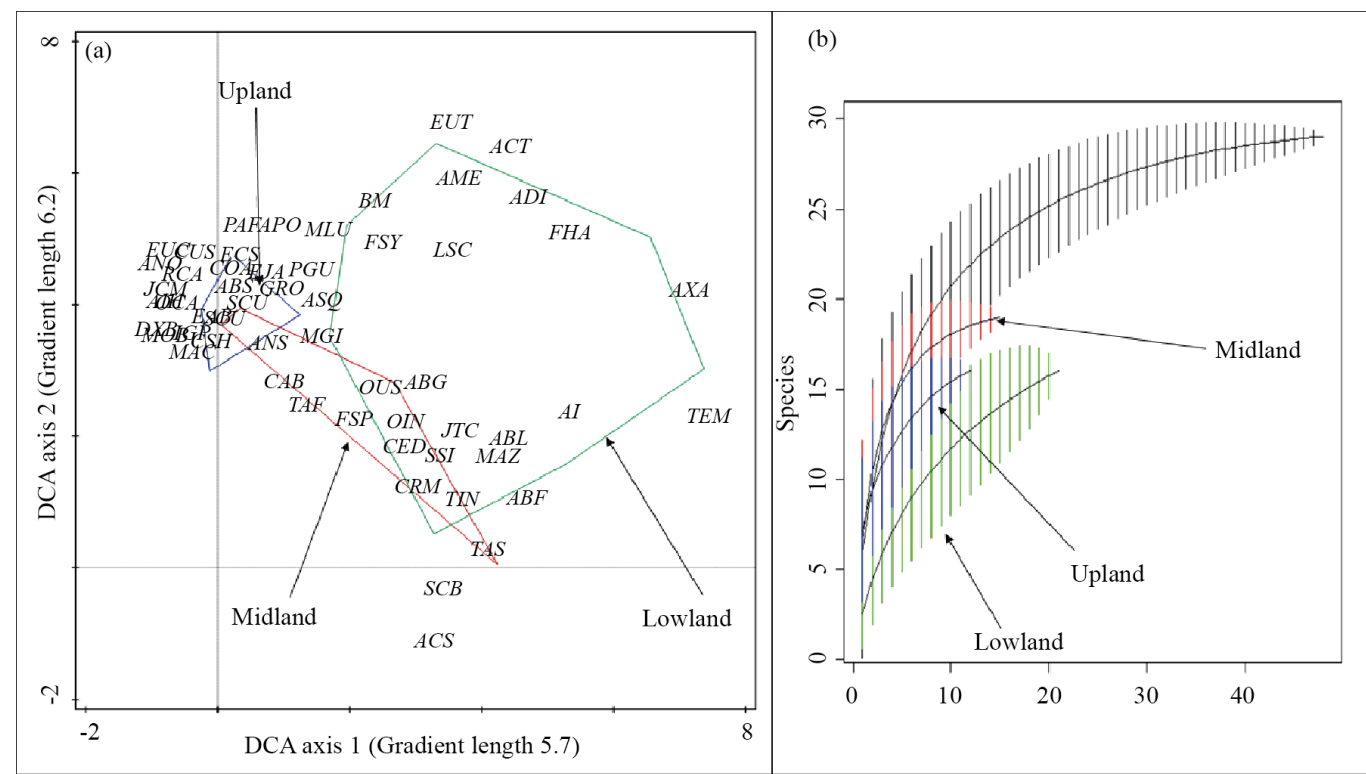

Figure 3. Species distribution (a) showing species spread with sites (species list in Table 1). Species accumulation curves (b) indicating species turnover in the study site on slopes of Mount Kilimanjaro, Tanzania. 

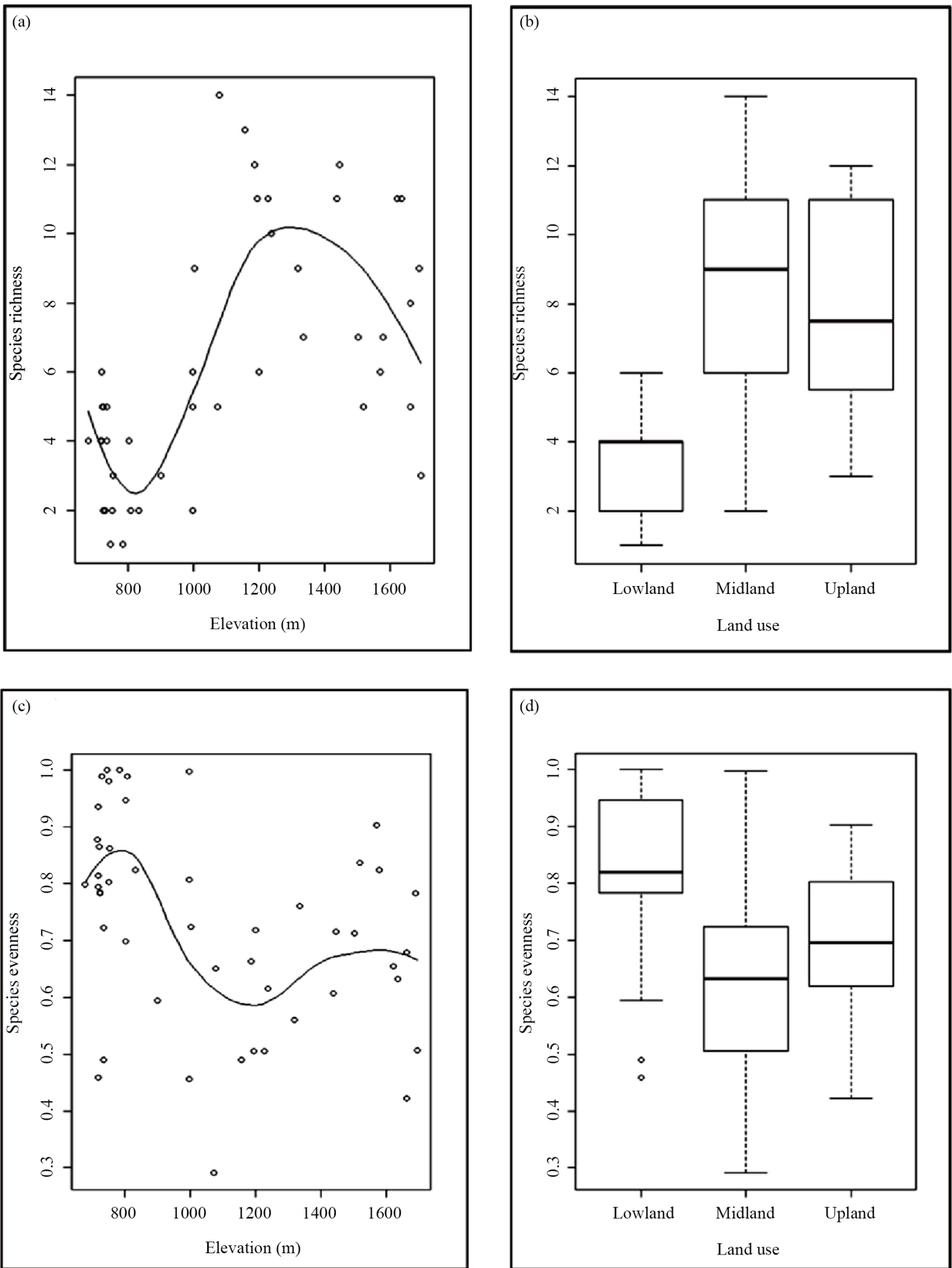

Figure 4. The relationship between altitude and land use with (a) - (b) species richness; and (c) - (d) species evenness. (a) and (c) are regression plots fitted with lines of best fit; (b) and (d) are box and whisker's plots representing the median values per plot. 


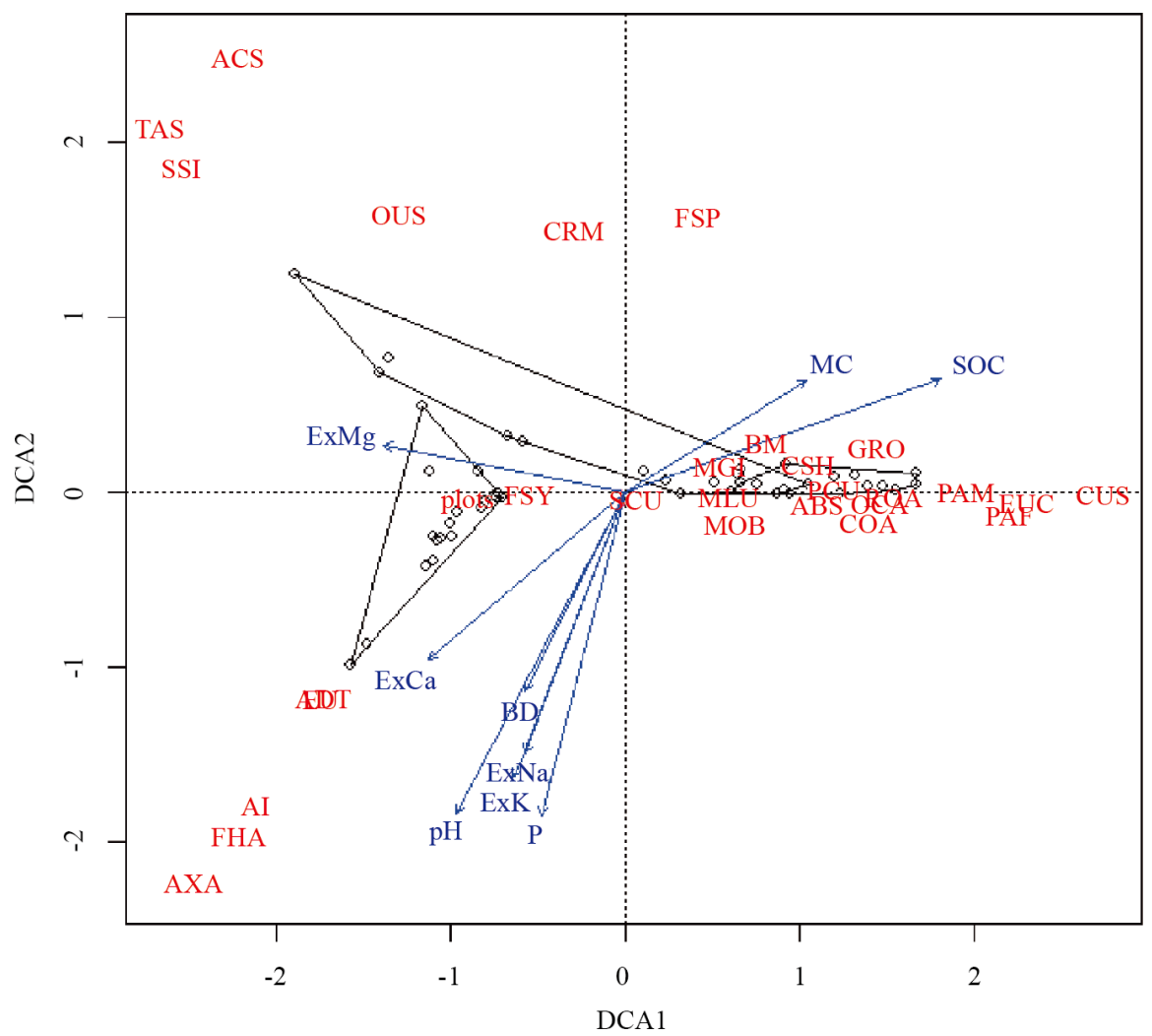

Figure 5. A triplot from a DCA of trees on farm on the slopes of Mount Kilimanjaro, Tanzania. Soil properties are represented by arrows. Polygons are the land uses categories. Three letters are the abbreviations of tree species (full list Table 1). Small square boxes are plots within the land use systems.

\section{Discussion}

\subsection{Tree Species Diversity}

Composition of tree species in the study area indicated a mixture of indigenous and exotic species almost in equal proportions (Table 3). While most of the indigenous species were remnants of natural forests, the exotic species were mainly from recent introductions. Botanical studies in the farmland in Kilimanjaro have identified most species (e.g. Table 3) to be forest species [38], while key exotic species like Avocado (Persea americana) were introduced in ca. 100 years ago [22] [39]. Tree were found to have multiple uses and their retention and/planting on farm has been common in other mountainous areas of Tanzania. Farmland further serves for ex-situ conservation of important tree species [8]. This study identified one species (Table 3) Prunus africana which has been listed as Vulnerable by the IUCN [40], due to its overexploitation in the wild for traditional medicine through debarking. Furthermore, trees on farm in the study site forms an important corridor connecting various forest patches including large blocks of Kilimanjaro Forest Reserve in the upper part and Kahe I \& II Forest Reserves in the lowland, which are about $30 \mathrm{~km}$ apart. Habitat connectivity is very important in ensuring unrestricted movement of the genetic material across major habitats [41].

The study observed distinct tree species communities associated with the three main land use systems in the region (Figure 3(a)). Heavy overcrowding of tree species was found in the upland and part of midland. This indicated that these tree species were closely related to one another and were influenced by similar conditions. The midland area indicated steepest rate of species accumulation (Figure 3(b)) indicating that high turnover was experienced in this zone than others. However, the causes of decline of species richness in upland are not clearly known (Figure 4(a) \& Figure 4(b)). Probably, one factor might be less activities of tree seeds dispersal agents in the upland. Higher presence of fruit-eating bats was noted [42] in the midland areas of the study site compared to the lowland and upland. This might have attracted more dispersal across various land uses but with main effect in the midland. The activity of dispersal agents has been crucial in establishment and effective colo- 
nization of tree species in landscapes [43]. In the contrary, the lowland contained few species but with higher number of individuals per species (Figure 4(c) \& Figure 4(d)). This might have indicated dominance of certain tree species due to adaptation to local factors, especially the saline conditions in the lowland.

\subsection{Soil Properties and Tree Species Distribution}

Soil properties (Figure 5, Table 2) were found to explain the distribution of the tree species in the study site among the major land use systems. The DCA indicated higher spread in the lowland and higher clustering in the upland and the midland areas. Lowland plant communities showed high positive loadings along Axis-1, whilst upland plant communities had shown negative loadings, with little overlap between the two. While some soil properties exerted positive correlations (SOC \& MC), the rest indicated negative correlation. This implies that affinity and tolerance to soil properties differ among tree species. For instance, distribution of Acacia xanthophloea was mainly found in the lowland where water-logged condition was predominant due to frequent floods in compacted soils that do not allow easy infiltration of water.

Strong and positive relationship for tree species with SOC and MC (Table 2, Figure 5), may explain higher concentration of the of tree species in the upland and midland. The increase in precipitation boost both soil moisture content and soil biota activities, which in turn enhance soil organic carbon. Improved SOC and MC attracts considerable number and varieties of tree species due to conducive environment for establishment and growth. Studies have shown that sensitivity of tree species to change in precipitation resulting into more growth in wet areas [44]. Similarly, soil properties especially moisture remained one of influential factor in other mountainous areas in Tanzania in defining vegetation zones (e.g., [45]). Furthermore, some tree species when established in high SOC soils have shown to contribute its stocks, as noted for Acacia mearnsii, contrary to other species in similar conditions [46].

A combination of soil properties such as soil $\mathrm{pH}$ and exchangeable bases (ExCa, ExK and ExNa) was noted to have negative correlation with tree species (Table 2, Figure 5) in the lowland. Generally, the soil condition in the lowland was very saline due to higher concentration of the exchangeable bases, which risen the soil $\mathrm{pH}$. This affected nutrient uptake by tree species and hence influenced their establishment. Similar observation was made in Brazilian savannah where tree species distribution and nutrient uptake was influenced by soil pH [47]. Saline conditions are known to hinder root activities of tree species, hence limit their establishment and growth [48]. De-salinization in order to reduce salty conditions in the lowland may probably be part of the solution to improve suitability of tree species to establish and grow.

Soil BD was found to have negative correlation with tree species in the lowland (Table 2, Figure 5).The BD increased with decreasing altitude, where lowland had higher BD compared to the upland and midland. Lowland soil BD was $0.7 \pm 0.03\left(\mathrm{~g} \cdot \mathrm{cm}^{-3}\right)$, which is within range that may cause growth-limiting conditions [49]. The restrictions of BD may include impairing root activities of the tree species and hence limit their capability of uptake of nutrients and water to support growth. However, despite higher BD, yet plant roots may grow due to biopores which offers alternative means to plants to access water and nutrients [50]. Therefore, only those plant tolerant to high $\mathrm{BD}$ and/or capable of using alternative means such as biopores may excel in colonizing the lowland areas of the study site.

\section{Conclusion}

Tree species in the study site were very diverse and provided multipurpose use to the local population. The distribution of the tree species was influenced by soil properties. Three distinct tree species groups were observed aligned and overlapped with land use zones. Soil properties varied with land use zones due to inherently parent material, bioclimatic processes and land management. This variation was responsible for soil conditions which were diverse and thus differed in accommodating tree species. SOC and MC correlated positively to large number of tree species especially in the upland and midland. In the lowland, soil pH, available P, BD and exchangeable bases (ExCa, ExK and ExNa) correlated negatively to tree species and became restrictive to others. Only ExMg was key soil nutrient in the midland and correlated positively with tree species. A likelihood existed that change in soil properties including addressing salinity, SOC and MC in the lowland could improve favourable conditions to accommodate spread of more tree species. This generated information has wide application in conservation strategies of trees on farm. 


\section{Acknowledgements}

This work was part of PhD program funded by the project titled "The Climate Change Impacts on Ecosystem Services and Food Security in Eastern Africa (CHIESA)”. CHIESA was funded by the Ministry for Foreign Affairs of Finland, and coordinated by the International Centre of Insect Physiology and Ecology (ICIPE) in Nairobi, Kenya. World Agroforestry Centre and CGIAR's CRP program on Humid Tropics supported Mathew Mpanda in various capacities. The authors are also grateful to the editor and reviewers for their suggestions towards completion of this paper.

\section{References}

[1] Guariguata, M.R., Cornelius, J.P., Locatelli, B., et al. (2008) Mitigation Needs Adaptation: Tropical Forestry and Climate Change. Mitigation and Adaptation Strategies for Global Change, 13, 793-808. http://dx.doi.org/10.1007/s11027-007-9141-2

[2] Harvey, C.A., Chacón, M., Donatti, C.I., et al. (2014) Climate-Smart Landscapes: Opportunities and Challenges for Integrating Adaptation and Mitigation in Tropical Agriculture. Conservation Letters, 7, 77-90. http://dx.doi.org/10.1111/conl.12066

[3] Mbow, C., Smith, P., Skole, D., et al. (2014) Achieving Mitigation and Adaptation to Climate Change through Sustainable Agroforestry Practices in Africa. Current Opinion in Environmental Sustainability, 6, 8-14. http://dx.doi.org/10.1016/j.cosust.2013.09.002

[4] Munishi, P.K.T., Philipina, F., Temu, R.P.C., et al. (2008) Tree Species Composition and Local Use in Agricultural Landscapes of West Usambaras Tanzania. African Journal of Ecology, 46, 66-73. http://dx.doi.org/10.1111/j.1365-2028.2008.00931.x

[5] Sinclair, F.L. (1999) A General Classification of Agroforestry Practice. Agroforestry Systems, 46, 161-180. http://dx.doi.org/10.1023/A:1006278928088

[6] Ndangalasi, H.J., Bitariho, R. and Dovie, D.B.K. (2007) Harvesting of Non-Timber Forest Products and Implications for Conservation in Two Montane Forests of East Africa. Biological Conservation, 134, 242-250. http://dx.doi.org/10.1016/j.biocon.2006.06.020

[7] Green, J.M.H., et al. (2013) Deforestation in an African Biodiversity Hotspot: Extent, Variation and the Effectiveness of Protected Areas. Biological Conservation, 164, 62-72. http://dx.doi.org/10.1016/j.biocon.2013.04.016

[8] Mpanda, M., Munjuga, M., Reyes, T., et al. (2014) Allanblackia, Butterflies and Cardamom: Sustaining Livelihoods alongside Biodiversity Conservation on the Forest-Agroforestry Interface in the East Usambara Mountains, Tanzania. Forests, Trees and Livelihoods, 23, 127-142. http://dx.doi.org/10.1080/14728028.2014.895215

[9] Zomer, R.J., et al. (2014) Trees on Farms: An Update and Reanalysis of Agroforestry’s Global Extent and SocioEcological Characteristics. Working Paper 179, World Agroforestry Centre (ICRAF) Southeast Asia Regional Program, Bogor, Indonesia, 33 p.

[10] Kuntashula, E. and Mafongoya, P.L. (2005) Farmer Participatory Evaluation of Agroforestry Trees in Eastern Zambia. Agricultural Systems, 84, 39-53. http://dx.doi.org/10.1016/j.agsy.2004.06.009

[11] Franzel, S., Akinnifesi, F.K. and Ham, C. (2007) Setting Priorities among Indigenous Fruit Tree Species in Africa: Examples from Southern, Eastern and Western Africa Regions. In: Akinnifesi, F.K., et al., Eds., Indigenous Fruit Trees in the Tropics: Domestication, Utilization and Commercialization, CAB International, Wallingford, Page No. 1. http://dx.doi.org/10.1079/9781845931100.0001

[12] Schoeneberger, M., et al. (2012) Branching out: Agroforestry as a Climate Change Mitigation and Adaptation Tool for Agriculture. Journal of Soil and Water Conservation, 67, 128A-136A. http://dx.doi.org/10.2489/jswc.67.5.128A

[13] Duguma, L.A., et al. (2013) Climate Smart Landscapes: Integrating Mitigation, Adaptation and Development in Shinyanga Region, Tanzania. ASB Partnership for the Tropical Forest Margins, Nairobi, 4.

[14] Warren, D.L. and Seifert, S.N. (2011) Ecological Niche Modeling in Maxent: The Importance of Model Complexity and the Performance of Model Selection Criteria. Ecological Applications, 21, 335-342. http://dx.doi.org/10.1890/10-1171.1

[15] Bedia, J., Herrera, S. and Gutiérrez, J.M. (2013) Dangers of Using Global Bioclimatic Datasets for Ecological Niche Modeling. Limitations for Future Climate Projections. Global and Planetary Change, 107, 1-12. http://dx.doi.org/10.1016/j.gloplacha.2013.04.005

[16] Aguirre-Gutierrez, J., Serna-Chavez, H.M., Villalobos-Arambula, A.R., Pérez de la Rosa, J.A. and Raes, N. (2014) Similar but Not Equivalent: Ecological Niche Comparison across Closely-Related Mexican White Pines. Diversity and Distributions, 21, 245-257. http://dx.doi.org/10.1111/ddi.12268 
[17] Son, T.C. and Halvorsen, R. (2014) Multiple Parallel Ordinations: The Importance of Choice of Ordination Method and Weighting of Species Abundance Data. Sommerfeltia, 37, 1-37. http://dx.doi.org/10.2478/som-2014-0001

[18] John, R., et al. (2007) Soil Nutrients Influence Spatial Distributions of Tropical Tree Species. Proceedings of the National Academy of Sciences of the United States of America, 104, 864-869. http://dx.doi.org/10.1073/pnas.0604666104

[19] Marage, D. and Gégout, J. (2009) Importance of Soil Nutrients in the Distribution of Forest Communities on a Large Geographical Scale. Global Ecology and Biogeography, 18, 88-97. http://dx.doi.org/10.1111/j.1466-8238.2008.00428.x

[20] Dalle, G., Maass, B.L. and Isselstein, J. (2014) Relationships between Vegetation Composition and Environmental Variables in the Borana Rangelands, Southern Oromia, Ethiopia. Ethiopian Journal of Science, 37, 1-12.

[21] Murphy, S.J., et al. (2015) Species Associations Structured by Environment and Land-Use History Promote Beta-Diversity in a Temperate Forest. Ecology, 96, 705-715. http://dx.doi.org/10.1890/14-0695.1

[22] URT (1998) Kilimanjaro Region Socio-Economic Profile. The Planning Commission and Regional Commissioner’s Office Kilimanjaro, Kilimanjaro, United Republic of Tanzania, 238.

[23] Soini, E. (2005) Land Use Change Patterns and Livelihood Dynamics on the Slopes of Mt. Kilimanjaro, Tanzania. Agricultural Systems, 85, 306-323. http://dx.doi.org/10.1016/j.agsy.2005.06.013

[24] Gall, B.L., Nonnotte, P., Rolet, J., Benoit, M., Guillou, H. and Nonnotte, P. (2008) Rift Propagation at Craton Margin. Distribution of Faulting and Volcanism in the North Tanzanian Divergence (East Africa) during Neogene Times. Tectonophysics, 448, 1-19.

[25] Schrumpf, M., Zech, W., Axmacher, J.C. and Lyaruu, H.V.M. (2006) Biogeochemistry of an Afrotropical Montane Rain Forest on Mt. Kilimanjaro, Tanzania. Journal of Tropical Ecology, 22, 77-89. http://dx.doi.org/10.1017/S0266467405002907

[26] Mowo, J.G., Floor, J., Kaihurm, F.B.S. and Magoggo, J.P. (1993) Review of Fertilizer Recommendations in Tanzania Part 2, S.F.R.N. 26, Editor, National Soil Service, Tanga, Tanzania.

[27] Zech, M., Hörolda, C., Leiber-Sauheitla, K., Kühnela, A., Hempc, A. and Zech, W. (2014) Buried Black Soils on the Slopes of Mt. Kilimanjaro as a Regional Carbon Storage Hotspot. Catena, 112, 125-130. http://dx.doi.org/10.1016/j.catena.2013.05.015

[28] Rohr, P.C. and Killingtveit, A. (2003) Rainfall Distribution on the Slopes of Mt Kilimanjaro. Hydrological Sciences Journal, 48, 65-77. http://dx.doi.org/10.1623/hysj.48.1.65.43483

[29] IUCN (2009) Pangani Basin: A Situation Analysis. 2nd Edition, International Union for Conservation of Nature Eastern and Southern Africa Programme, 82.

[30] NAFORMA (2010) Species List Sorted by Vernacular Names (Common Names). F.a.B. Division, Editor, Ministry of Natural Resources and Tourism Tanzania, Dar es Salaam, 80.

[31] UNEP (2012) Land Health Surveillance: An Evidence-Based Approach to Land Ecosystem Management. Illustrated with a Case Study in the West Africa Sahel. United Nations Environment Programme, Nairobi, Kenya.

[32] Towett, E.K., Shepherd, K.D., Sila, A., Betemariam, E. and Cadisch, G. (2015) Mid-Infrared and Total X-Ray Fluorescence Spectroscopy Complementarity for Assessment of Soil Properties. Soil Science Society of America Journal, 79, 1375-1385. http://dx.doi.org/10.2136/sssaj2014.11.0458

[33] Savitzky, A. and Golay, M. (1964) Smoothing and Differentiation of Data by Simplified Least Squares Procedures. Annals of Chemistry, 36, 1627-1639. http://dx.doi.org/10.1021/ac60214a047

[34] R Development Core Team (2013) R: A Language and Environment for Statistical Computing. R Foundation for Statistical Computing, Vienna, Austria.

[35] Sila, A., Hengl, T. and Terhoeven-Urselmans, T. (2014) soil.spec: Soil Spectroscopy Tools and Reference models.

[36] Peet, R.K., Knox, R.G., Case, J.S. and Allen, R.B. (1988) Putting Things in Order: The Advantages of Detrended Correspondence Analysis. The American Naturalist, 131, 924-934. http://dx.doi.org/10.1086/284833

[37] Van Goethem, T.M.W.J., Huijbregtsa, M.A.J., Wieger Wamelinkb, G.W. and Schippera, A.M. (2015) How to Assess Species Richness along Single Environmental Gradients? Implications of Potential versus Realized Species Distributions. Environmental Pollution, 200, 120-125. http://dx.doi.org/10.1016/j.envpol.2015.02.017

[38] Hemp, A. (2005) The Banana Forests of Kilimanjaro: Biodiversity and Conservation of the Chagga Homegardens. Biodiversity and Conservation, 15, 1193-1217. http://dx.doi.org/10.1007/s10531-004-8230-8

[39] Gaillard, J.P. and Godefroy, J. (1995) Avocado. In: Coste, R., Ed., The Tropical Agriculturist Series (CTA, Macmillan) Education Ltd., London.

[40] IUCN (2016) The IUCN Red List of Threatened Species. Version 2015-4.

[41] Ripperger, S.P., Kalko, E.K.V., Rodríguez-Herrera, B., Mayer, F. and Tschapka, M. (2015) Frugivorous Bats Maintain 
Functional Habitat Connectivity in Agricultural Landscapes but Rely Strongly on Natural Forest Fragments. PLoS ONE, 10, e0120535. http://dx.doi.org/10.1371/journal.pone.0120535

[42] Helbig-Bonitz, M., Rutten, G. and Kalko, E.K.V. (2014) Fruit Bats Can Disperse Figs over Different Land-Use Types on Mount Kilimanjaro, Tanzania. African Journal of Ecology, 52, 122-125. http://dx.doi.org/10.1111/aje.12090

[43] Howe, H.F. and Smallwood, J. (1982) Ecology of Seed Dispersal. Annual Review of Ecology and Systematics, 13, 201228. http://dx.doi.org/10.1146/annurev.es.13.110182.001221

[44] Sanchez-Huerta, J.S. and Pompa-García, M. (2014) Climatic Influences on Basal Area Increment of Forests in a Mountainous Landscape. Annual Research \& Review in Biology, 4, 1361-1371. http://dx.doi.org/10.9734/ARRB/2014/6957

[45] Hamilton, A.C. and Bensted-Smith, R. (1989) Forest Conservation in the East Usambara Mountains Tanzania. Gland and Cambridge: IUCN (The World Conservation Union) and Forest Division, Ministry of Lands, Natural Resources and Tourism.

[46] Kasel, S., Singha, S., Sandersb, G.J. and Bennettb, L.T. (2011) Species-Specific Effects of Native Trees on Soil Organic Carbon in Biodiverse Plantings across North-Central Victoria, Australia. Geoderma, 161, 95-106. http://dx.doi.org/10.1146/annurev.es.13.110182.001221

[47] Viani, R.A.G., Rodrigues, R.R., Dawson, T.E., Lambers, H. and Oliveira, R.S. (2014) Soil pH Accounts for Differences in Species Distribution and Leaf Nutrient Concentrations of Brazilian Woodland Savannah and Seasonally Dry Forest Species. Perspectives in Plant Ecology, Evolution and Systematics, 16, 64-74. http://dx.doi.org/10.1016/j.ppees.2014.02.001

[48] Hironaka, M., Fosberg, M.A. and Neiman, K.E. (1990) The Relationship between Soil and Vegetation. Management and Productivity of Western-Montane Forest Soils, Boise, 10-12 April 1990, 29-31.

[49] Raison, R.J., Brown, A.G. and Flinn, D.W. (2001) Criteria and Indicators for Sustainable Forest Management. IUFRO Research Series 7, CABI Pub., New York, 462.

[50] Stirzaker, R.J., Passioura, J.B. and Wilms, Y. (1996) Soil Structure and Plant Growth: Impact of Bulk Density and Biopores. Plant and Soil, 185, 151-162. http://dx.doi.org/10.1007/BF02257571 